\title{
PECULIARITIES OF THE INTERNATIONALIZATION OF SMALL AND MEDIUM AGRO-ENTERPRISES
}

\author{
Tošo Kostadinov \\ Institute of Animal Science, Ss. Cyril and Methodius University in Skopje, \\ Blvd. Ilinden 92a, Skopje, Republic of North Macedonia \\ tosokostadinov@gmail.com
}

\begin{abstract}
$\mathrm{A} \mathrm{b} \mathrm{s} \mathrm{t} \mathrm{r} \mathrm{a} \mathrm{c} \mathrm{t:} \mathrm{Internationalization,} \mathrm{as} \mathrm{a} \mathrm{term,} \mathrm{is} \mathrm{used} \mathrm{in} \mathrm{the} \mathrm{process} \mathrm{of} \mathrm{involving} \mathrm{and} \mathrm{intensifying} \mathrm{international}$ operations. It describes the continuum that begins with the first import activity or extra regional expansion ("domestic internationalization") until complete globalization. It includes activities such as export, licensing, franchising, management contracts, turnkey contracts, production contracts / international pre-contracts, industrial cooperation agreement, integration, takeover, strategic alliances, etc. The purpose of this research is to obtain information on the condition of SMEs from the agro-complex, compared to a research conducted in 2007. For that purpose, a survey questionnaire was prepared, a survey was conducted, the data were processed and analyzed, which helped us to show that situation. The results of the research indicate a certain shift of the SME stage of the agro-complex to a higher level of their internationalization.
\end{abstract}

Key words: SMEs from the agro-complex; internationalization; globalization;, competitiveness;1, promotion of internationalization

\section{ПОСЕБНОСТИ НА ИНТЕРНАЦИОНАЛИЗАЦИЈАТА НА МАЛИТЕ И СРЕДНИ АГРОПРЕТПРИЈАТИЈА}

А п с т р а к т: Интернационализацијата, како термин, се применува во процесот на инволвирање и интензивирање на интернационални операции. Со тој термин се опишува континуитетот којшто започнува со првата увозна активност или вонрегионална експанзија (,домашна интернационализација“), па сѐ до целосна глобализација. Таа вклучува активности како што се извоз, лиценцирање, франшизинг, менаџерски договори, договори клуч на рака, договори за производство/интернационални преддоговори, согласност за индустриска кооперација, интеграција, преземање, стратешки алијанси и сл. Целта на ова истражување е да се добијат информации за состојбата на мали и средни претпријатија (МСП) од агрокомплексот, споредени со едно истражување спроведено во 2007 година. За таа цел беше изготвен анкетен прашалник, беше спроведено анкетно истражување, податоците беа обработени и анализирани, што помогна да се прикаже таа состојба. Резултатите од истражувањето укажуваат на извесно поместување на стадиумот на МСП од агрокомплесот кон повисоко ниво на интернационализација.

Клучни зборови: МСП од агрокомплексот; интернационализација; глобализација; конкурентска способност; промовирање на интернационализација

\section{INTRODUCTION}

While we must admit that most authors believe that internationalization is related to large enterprises, this is only partially true. Small, especially medium-sized enterprises, tend to grow [3]. Internationalization appears as the only solution to that aspiration. The reason for this is simple: small-sized and medium-sized enterprises do not have a wide range of products, or are focused on one - usually narrow - product range. To achieve economies of scale, businesses must look for new markets. Indeed, this is especially true for niches, which are usually small. Larger 
companies are usually better internationalized, because they have more financial and managerial resources, have larger production facilities, larger economies of scale and are exposed to less risk in export operations [2].

The internationalization of small and medium enterprises is influenced by factors that hinder it and factors that encourage internationalization. Some of the factors that encourage or hinder the internationalization of small and medium enterprises are:

- Attention, dedicated to meeting the needs of consumers. Here, SMEs often have difficulties, because they repeatedly lack the resources to properly meet market needs [1].

- The quality of products on the foreign market is often higher than on the domestic market, which, of course, hinders internationalization.

- Characteristics of management and coverage of management needs. SME managers compared to large companies often have lower relevant education and are less successful in operating in foreign markets.

- International experience, obtaining information on foreign markets, as well as general support of the environment (country) in internationalization. Trade barriers between countries (both official and non-official, for example, the relationship to the origin of goods) hinder the internationalization of all enterprises. International experience and facilitated access to information on the state of foreign markets encourage internationalization.

These are just some of the factors that affect the internationalization of SMEs. Small and medium-sized enterprises often have greater export difficulties than larger enterprises. Reasons for the difficulties are: bureaucratic obstacles, non-customs obstacles, late payment, the choice of distributor as well as communication difficulties with foreign customers. Therefore, they need to help each other, so that in new markets they will appear in some new forms, for example, networked with foreign smaller companies or in an export consortium.

According to an OECD study, in developed countries small and medium-sized enterprises differ from large enterprises in the following characterristics [3]:

- They lack strategic planning, so, most often, they deal with internationalization in a less efficient way.
- Strategy based on evolution - lack of strategy planning is often a consequence of lack of opportunities, so that SMEs often only take advantage of the opportunities offered to them. Such an approach is very opportunistic, i.e. there is no proactive approach.

- Companies that pay more attention to planning, often choose a combination of different strategic opportunities.

- The inclination towards internationalization increases with the maturity of the enterprise. The maturity of the enterprise here is measured by meeting the goals of the domestic market.

- The propensity for independent internationalization is often a consequence of family ownership, which tends to remain independent in the process of internationalization, although it is not the best solution.

- Some business functions are better internationalized than others.

- There is no single strategy for success - this means that if companies do not have their own clear vision of development, they cannot accurately determine the tools with which to meet the goals. Every company that intends to be present in the international markets should create its own strategy.

If we connect the internationalization of SMEs with their level of entrepreneurial development, we can classify enterprises according to the following model. There are four modalities of an internationalized enterprise:

- Enterprises that are not internationalized, and are less entrepreneurial,

- Enterprises that are not internationalized, but are entrepreneurial,

- Enterprises that are internationalized, and less entrepreneurial, and

- Enterprises that are internationalized and entrepreneurial.

\section{MATERIAL AND METHODS OF WORK}

The purpose of this research is based on literature, documents and especially on the analysis of the Questionnaire on a random sample of agroentrepreneurs from RNM. The research uses several methods used in social and economic analysis such as: generalization and specialization, induction and deduction, statistical and comparative method. 


\section{ANALYSIS AND DISCUSSION}

Kostadinov and Pendev [5] in their research in 2007, on the claims made in the survey questionnaire related to determining the degree of internationalization of the company, the respondents stated as follows:

- The company procures from abroad. $32.0 \%$ of the respondents do not agree at all, $4.0 \%$ partially disagree, $2 \%$ answered neither yes nor no, $6.0 \%$ partially agree, and 56.0 completely agree $\%$ of respondents.

- The company exports abroad. In general, $50.0 \%$ of the respondents do not agree, $6.0 \%$ partially disagree, $10.0 \%$ partially agree, and $34.0 \%$ completely agree.

- The company directly invests abroad. $88.0 \%$ do not agree at all, neither yes nor no answer $6.0 \%, 2 \%$ partially agree, and $4.0 \%$ completely agree.

- The company works abroad through foreign business partners. From the respondents, $34.0 \%$ do not agree at all, $2.0 \%$ answered neither yes nor no, $26.0 \%$ partially agree, and $38.0 \%$ completely agree.

- The company was international from the very beginning. $84.0 \%$ of the respondents do not agree with this statement at all, $2.0 \%$ partially disagree, neither yes nor did not answer $4.0 \%$, and $10.0 \%$ of the respondents completely agree.

- The company works exclusively on the domestic market. $30.0 \%$ of the respondents do not agree at all, $8.0 \%$ partially disagree, $10.0 \%$ partially agree, and $52.0 \%$ completely agree.

- The company aims to enter new foreign markets. $18.0 \%$ do not agree with this statement at all, $6.0 \%$ partially disagree, neither yes nor no answered $14.0 \%$, partially agree $6.0 \%$, and $56.0 \%$ completely agree.

In our research in 2019, the respondents stated in the survey questionnaire that refers to determining the degree of internationalization of the company, the respondents said:

- The company procures from abroad. $17.0 \%$ of the respondents do not agree at all, $2.0 \%$ partially disagree, $2 \%$ answered yes or no, $3.0 \%$ partially agree, and $76 \%$ completely agree respondents.

- The company exports abroad. $30.0 \%$ of the respondents do not agree at all, 3.0\% partially disagree, $10.0 \%$ partially agree, and $57.0 \%$ completely agree.
- The company directly invests abroad. $68.0 \%$ do not agree at all, neither yes nor $5.0 \%$ did not answer, $2 \%$ partially agree, and $25.0 \%$ completely agree.

- The company works abroad through foreign business partners. From the respondents, $25.0 \%$ do not agree at all, $2.0 \%$ answered neither yes nor no, $20.0 \%$ partially agree, and $53.0 \%$ completely agree.

- The company was international from the very beginning. $80.0 \%$ of the respondents do not agree with this statement at all, $2.0 \%$ partially disagree, neither yes nor no answered $4.0 \%$, and $14.0 \%$ of the respondents completely agree.

- The company works exclusively on the domestic market. $50.0 \%$ of the respondents do not agree at all, $8.0 \%$ partially disagree, $10.0 \%$ partially agree and $32.0 \%$ completely agree.

- The company aims to enter new foreign markets. $10.0 \%$ do not agree at all with this statement, $6.0 \%$ partially disagree, neither yes nor no answered $10.0 \%, 6.0 \%$ partially agree, and $68.0 \%$ completely agree.

\section{CONCLUSION AND RECOMMENDATIONS}

As a basic conclusion of this research is that the results of the research indicate a certain shift of the SME stage from the agro-complex to a higher level of their internationalization in the period 2007-2020.

Recommendations for assistance to the internationalization of SMEs according to the SME classification are given in the Table 1.

SMEs that are internationalized but less entrepreneurial are those that are already in international markets but lack the motivation to develop in those markets. Such companies may have accidentally started exporting, receiving a random foreign order, or externally reacting to incentives. The focus of the policy here should be on ensuring that such SMEs receive a positive response from their international market presence. Measures should include providing appropriate assistance, information, training, counseling, operational problem relief, hiring agents or assistance in hiring more managers with appropriate qualifications, encouraging private sector organizations to get involved in their networks, giving opportunity for exchange of experience and training, etc.

Finally, the policy focus on internationalized and entrepreneurial SMEs should be on retaining 
their key components and rebuilding their international and entrepreneurial vision. Such enterprises need to have a continuous response to the comparative challenges of the changing globalized market with appropriate adjustments and innovations in products, processes, organization, markets and technology.

Table 1

Recommendations for assistance in internationalization of SMEs according to SME classifications

\begin{tabular}{|c|c|c|}
\hline & Entrepreneurial & Less entrepreneurial \\
\hline \multirow{2}{*}{ 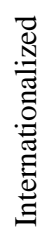 } & (4) & (3) \\
\hline & $\begin{array}{l}\text { Offer of best practices for research and development } \\
\text { and innovation. Participation in network structures. } \\
\text { Assistance in operational problems, foreign clients, } \\
\text { market access, etc. }\end{array}$ & $\begin{array}{l}\text { Request for positive reinforcement of interna- } \\
\text { tionalization. Setting up a liaison officer / problem } \\
\text { solver. Network activities, export clubs. }\end{array}$ \\
\hline \multirow{2}{*}{ 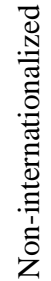 } & (2) & (1) \\
\hline & $\begin{array}{l}\text { Help for building competence. Providing consulting } \\
\text { support and training. Facilitate access to available } \\
\text { support. Mentoring scheme offer. Offer the best } \\
\text { experiences, research and development, innovation, } \\
\text { networks. }\end{array}$ & $\begin{array}{l}\text { Involvement of exchange agents. Providing training } \\
\text { support and information. Assistance for contact in } \\
\text { foreign markets. Offer to enter the network. } \\
\text { Establishment of brokers for international markets. }\end{array}$ \\
\hline
\end{tabular}

Additional attention should be paid to the attitude towards key market activities (regular market visits, etc.), and in particular to give empirical support for the potential benefits of the activities. SMEs in this category, relatively speaking, require less help from the government and its agencies. Government assistance should be most present in minimizing operational or access problems in foreign markets. This is a standard government service for businesses to help increase their international competitiveness. Such initiatives are significant because they lead to reduced research and development costs, access to new technologies, improved product quality, increased product reputation in the country, the creation of new markets, and increased SME networking. Internationally and globally.

\section{REFERENCES:}

[1] Briclin, D. (2001): Natural-Born Enterpreneur, Harvard Busines, Schppl Publishing Corporation.

[2] Davidson, P. \& Honig, B. (2003): The role of social and human capital among nescent entrepreneurs, Journal of Busines Venturing, 18 (3).

[3] Drucker, F. P. (1999): Menagement Challenges for 21 $1^{\text {st }}$ Century, B. K. Harper Business, New York.

[4] Edvinson, L \& Melone, M. S. (1997): Intellectual Capital, New York, NY: Harper Collins Publishers.

[5] Kostadinov, T., Pendev, D. (2007): Small and medium enteprises in the agrocomplex from the vievpoint of the internacionalization, III Symposium "Liverstok, Production with International Participacium" Ohrid 2007, pp. 135-141.

[6] Nonaka, I. \& Takeuchi, H. (1995): The Knowledge-Creating Company, New York, Oxford University Press. 